\title{
Conference Group for Central European History
}

\section{Newsletter}

\section{Spring 1998}

\section{Dear Colleagues,}

Here is the spring 1998 Newsletter. It contains several items of interest. The January business meeting voted to make some changes with respect to the allocation of funds. There is our biennial book prize announcement as well as the report of last year's article prize committee. There is a new and reenergized archives committee, and the executive committee has issued a statement concerning the use of legal means to settle academic disputes.

\section{Kees Gispen}

\section{Business Meeting, Seattle, Washington 10 January 1998}

Introduction. President Sybil Milton chaired the meeting and introduced Gerald Soliday, who will serve as president until January of 1999 . The minutes of last year's business meeting were approved.

Report of the Executive Secretary and Treasurer. Kees Gispen reported on the Conference Group's finances. He presented the following overview.

In light of the healthy state of the Conference Group's finances, Gispen on behalf of the Executive Committee moved to increase the Conference Group's subsidies to Central European History (from $\$ 1,500$ to $\$ 2,500$ per year) and the National Coordinating Committee for the Promotion of History (from $\$ 300$ to $\$ 400$ ), as well as an increase in the amount of the book prize (from $\$ 500$ to 
Income

AHA interest

400.00

HPI royalties

$5,045.00$

Total income

$5,445.00$

Expenses

Contrib. Friends of GHI

150.00

Book prize

500.00

Hilton Hotel NY Bierabend

941.78

1996 Fall Newsletter

776.96

1997 NCC dues

300.00

Subsidy to $\mathrm{CEH}$

$1,500.00$

Savings at AHA

$1,000.00$

Bank check printing charge

11.85

Subsidy Transatlantic Seminar

$1,000.00$

Net Income

Total expenses

$6,180.59$

Balance Forward, 19 January 1998

$<735.59>$

$5,952.05$

$\$ 750$ ). Following discussion, this proposal was accepted by voice vote, with the understanding that the subsidy to the NCC will go from $\$ 300$ to $\$ 500$.

The budget for 1998/99 therefore looks as follows (see p. 639).

Report of the Editor of Central European History. Kees Gispen reported for Ken Barkin, who was unable to attend the business meeting, on the state of Central European History. In 1997, four issues were published, Vol. 29, nos. 3 and 4 (imprint 1996), Vol. 30, nos. I and 2 (imprint 1997). Volume 30, no. 3 was at the publisher's at reporting time, and volume 30 , no. 4 was scheduled to go to the publisher on 1 February 1998. Progress toward catching up with the present is continuing and nearly complete. At 1011, the number of subscriptions is one more than last year. Approximately half of all subscriptions are with institutions. A brief statistical summary of CEH publishing in 1997 follows (see p. 640).

Report of the 1997 Prize Committee. The next item of business was the report of the 1997 prize committee, which consisted of David Blackbourn, Heide Fehrenbach and Larry Jones (chair). Since none of the members of the prize 


\section{Budget Proposal January 1998-January 1999}

Balance Forward, 10 January 1998

$\$ 5,952.05$

Projected Income

AHA interest

425.00

HPI royalties*

$3,000.00$

Total projected income

Projected Expenses

Book prize award, Jan. 1998

500.00

Sheraton Bierabend, Jan. 1998

250.00

1998 NCC dues

400.00

1998 Subsidy to $\mathrm{CEH}$

$2,500.00$

1998 Subsidy Transatl. Seminar $\quad 1,000.00$

1998 Savings at AHA

$1,000.00$

Net Income

Total projected expenses

Balance Forward, January 1998

$<2,225.00\rangle$

$3,727.05$

*Explanation of HPI (Humanities Press International) royalty decrease. In the recent past, Humanities Press International, publisher of Central European History, has paid royalties to the Conference Group in December of each year. The Conference Group's treasurer was informed that this practice is at variance with the HPI's customary practice of paying its annual royalties in April of the following year and therefore presents HPI with some inconvenience. HPI has suggested that the payment date be moved up from December of the current year to April of the following year. Following discussion between the treasurer and HPI a compromise was proposed, under which HPI would continue to pay an advance on royalties in the fall of the current year and then pay the balance in April of the following year. The Executive Board approved this proposal. The proposed amount of the advance has been set at $\$ 3,000.000$, resulting in a net decrease of the Conference Group's 1998 royalty income from HIPI of approximately \$2,045.00. Assuming subscriptions stay at their current level, the 1999 royalty income from HPI will revert to the 1997 level of a little over $\$ 5,000.00$.

committee was able to come to Seattle, Sybil Milton presented the report. The committee awarded the article prize to Robert Moeller and gave honorable mention to Lisa Heineman. The text of the committee's report follows below.

The article prize committee of the Conference Group for Central European History of the American Historical Association considered nearly forty articles for its biennial award for the best article in the general field of Central European history. The articles either appeared in Central European History between 1994 and 1996 or were nominated by members of the Conference Group for Central European History. They were then judged on the basis of their significance as scholarly contributions to the existing body of secondary literature in the field of Central European history. Special attention was devoted to the extent and thoroughness of the primary research, the origi- 


\section{Publishing Record for 1997: 4 Issues}

\begin{tabular}{lcccc} 
& Articles & Review Articles Book Reviews & Other \\
\hline Vol. 29, no. 3 & 3 & 2 & 21 & 0 \\
Vol. 29, no. 4 & 2 & 2 & 15 & 0 \\
Vol. 30, no. 1 & 3 & 1 & 23 & 0 \\
Vol. 30, no. 2 & 4 & 1 & 17 & 2 \\
Total 1997 & 12 & 6 & 76 & 2 \\
At Publisher's & & & & \\
$\quad$ Vol. 30, no. 3 & 3 & 1 & 20 & 1 \\
In Progress & & & & \\
Vol. 30, no. 4 & 3 & 1 & 20 & 0 \\
\hline
\end{tabular}

Current editorial status:

Articles accepted: 4

Articles to be revised: 3

Articles at referees: 5

Articles received and to be read: 3

Articles rejected in 1997: 22

Book reviews on hand: 43

Book reviews outstanding: 125

Subscribers: 1,011

nality and cogency of the article's thesis, and the quality and clarity of the author's writing style.

The prize committee was impressed by the high quality of the entries, whose diversity, originality, and intellectual rigor testified to the vitality of work in the field of Central European history. After extensive deliberation, the prize committee's choice was Robert G. Moeller for his article, "War Stories: The Search for a Usable Past in the Federal Republic of Germany" in the October 1996 issue of The American Historical Review. Professor Moeller's article represents a significant and original contribution to the recent debate about the construction of Germany's postwar national identity. By focusing on the stories of those Germans who had been expelled from Eastern Germany and Eastern Europe at the end of World War II as well as on those of German soldiers who had been imprisoned in the Soviet Union, Professor Moeller analyzes the ways in which these stories were "crafted into rhetorics of victimization in the arena of public policy and in the writing of "contemporary history." Focusing on stories of Communist brutality and the loss of the "German East" thus made it possible for West Germans "to talk about the end of the Third Reich without assessing responsibility for its origins" and "to tell an abbreviated story of National Socialism in which all Germans were ultimately victims of a war that Hitler started but everyone lost." Professor Moeller brings a fresh perspective to Germany's ongoing search for a usable past and reminds us in light of the events of 1989-90 how 
powerful this image of the past remains in Germany's contemporary historical consciousness. By virtue of its erudition and originality, Professor Moeller's article will remain a major contribution to what is certainly one of the most vexing problems of culture and politics in modem German history.

The prize committee would like to use this opportunity to take special notice of another article that it deemed highly meritorious and worthy of honorable mention. The committee would like to recognize Elizabeth Heineman for her article, "The Hour of the Woman: Memories of Germany's 'Crisis Years' and West German National Identity," in the April 1996 issue of The American Historical Review."

Report of the Nominating Committee. Next on the agenda was the report of the 1997 nominating committee, comprising Omer Bartov, Kathleen Canning, and Helmut Walser Smith. Since none of the committee members was present, Sybil Milton announced the committee's nominations, which were approved by voice vote.

Vice-President Elect: Mary Jo Maynes

Executive Committee (a two-year term): Anson Rabinbach

Executive Committee (a three-year term): Mary Lindemann

The term of service for each of the above positions commenced on 11 January 1998.

Report of the Archives Committee. The Archives Committee of the Conference Group was reconstituted and expanded at the AHA meeting in Seattle in January 1998. The committee is now composed as follows:

David Barclay,

John Connelly,

Carole Fink, Geoffrey Giles, Alan Steinweis,

Gerhard Weinberg,
Kalamazoo College

University of California, Berkeley

Ohio State University

University of Florida (ex officio)

University of Nebrasca at Lincoln (chair)

University of North Carolina at Chapel Hill

In view of the commonality of interests between the Conference Group for Central European History and many members of the German Studies Association (GSA), committee chair Alan Steinweis held discussions with Geoffrey Giles, chair of the GSA Archives Committee, about how the Archives Committees of the two associations might coordinate their activities. They decided that one way to promote cooperation would be by appointing the chair- 
person of each committee to an ex officio seat on the other. The Conference Group's Executive Committee approved this experimental arrangement.

The Archives Committee serves as a clearinghouse of information about research conditions in archives that are relevant to the work of historians of German-speaking Europe. The interests of the committee are, therefore, not limited to archives in Germany, Austria, and Switzerland, but also include pertinent depositories in the United States (e.g., the National Archives) and other countries.

Members of the Conference Group who have experienced problems in attempting to carry out archival research are encouraged to inform the Archives Committee. Typical problems involve denial of access to files, nonresponses to inquiries, seriously substandard reading room facilities, and exorbitant fees for photocopying and postage.

The Archives Committee can communicate information about such problems to the community of Central European historians through this Newsletter and on the H-German History Internet discussion list. In cases of problems of a particularly serious and systematic nature, the Committee, in consultation with the Executive Committee, will communicate directly with the appropriate archival authorities in order to seek clarification and, if necessary, remedial action. In such cases the Committee may also, through the Chair and the Executive Secretary of the Conference Group, enlist the support of the American Historical Association, the National Coordinating Committee for the Promotion of History, and similar organizations.

Please address all communications to:

Alan E. Steinweis, Chair, CGCEH Archives Committee

Department of History

University of Nebraska at Lincoln

Lincoln, NE 68588-0327

Phone:(402) 472-8839

Fax:(402) 472-8839

Email: aes@unlinfo.unl.edu

Report of Friends of the German Historical Institute. Geoffrey Giles spoke on behalf of Friends of the German Historical Institute in Washington. He reminded everyone of the dissertation prize awarded by "Friends," announced that "Friends" had achieved taxexempt status, and mentioned that membership in "Friends" is now on an individual rather than an institutional basis. He urged 
everyone to become a member of the group. The treasurer of Friends of the German Historical Institute is Jonathan Petropoulos, Department of History, Loyola College, 4501 North Charles Street, Baltimore, MD 21210, telephone: (410)617-2000. Email: petropoulos@loyola.edu

Report from the Society for Austrian and Habsburg History. On behalf of the SAHH, Lawrence Sondhaus reported that as of June 1997 the SAHH is an autonomous association and an affiliate of the AHA in its own right. The SAHH will retain its close affiliation with the CCGEH. Sondhaus's successor as Executive Secretary of the SAHH is Mary Gluck, Department of History, Brown University, Providence, RI 02912, telephone: (401) 863-2352. Email: mary_gluck@brown.edu.

New Business. Speaking on behalf of the Executive Committee, Sybil Milton brought up two new issues.

Change in time of business meeting and Bierabend. The first issue concerned a proposed change in the time of the business meeting and the Bierabend. Following discussion, the business meeting voted to change the time of the business meeting in 1999 to 5 P.M., or immediately after conclusion of the last Saturday session, to be followed by the Bierabend from 6 P.M. to 7 P.M. The rationale for this experimental change is to make it possible for colleagues and members to attend both the business meeting/Bierabend and not disrupt the Saturday evening any more than necessary. The hope and expectation is that this will increase attendance at the Conference Group's official functions.

Statement on the use of legal means to settle academic disputes. The second and last matter prior to adjournment concerned the controversy, discussed at length on $\mathrm{H}-$ German and in other venues, raised by reports that Daniel Jonah Goldhagen may be considering the use of legal means to settle an academic dispute with Ruth Bettina Birn. Sybil Milton asked Gerhard Weinberg, who was in the audience, to give a brief report on the status of this issue, to the extent that Weinberg was informed about it. Following Weinberg's informal presentation and some discussion by various other members present, the business meeting voted without dissent to charge the executive committee with drafting a position statement in the matter.

\section{Announcements \\ CGCEH Statement on the Use of Legal Means to Settle Academic Disputes}

In accordance with instructions received at the January business meeting, the Executive Committee has approved and now issues the following statement. 
During the fall of 1997, the electronic discussion group, H-German, published a series of comments on the recourse to legal action, or the threat thereof, in connection with a critical review by the Canadian scholar, Ruth Bettina Birn, of Daniel Jonah Goldhagen's Hitler's Willing Executioners: Ordinary Germans and the Holocaust. The material in question and other pertinent information can be found on the World Wide Web by accessing the home page of H-German (http://www.h-net.msu.edu/-german) and going to the link, "Goldhagen's Hitler's Willing Executioners."

The Executive Committee of the Conference Group for Central European History considers that the recourse to legal action in scholarly disputes threatens the fundamental principles of academic discourse and debate. While we recognize that in some unique situations it may be justified to seek redress through the courts, we believe that legal action or the threat of legal action is not an appropriate way of resolving differences of interpretation, evidence, and analysis. These differences are best addressed in free and open debates among scholars. Any curtailment of such debates has a chilling effect on the free exchange of ideas upon which all scholarship ultimately depends.

The Executive Committee has agreed to submit this statement and introduction to the Professional Division of the American Historical Association, the American Political Science Association, the National Coordinating Committee for the Promotion of History, and the two scholars mentioned in the introduction.

\section{CGCEH Book Prize}

The Conference Group for Central European History sponsors a biennial competition for a $\$ 750$ prize for the best book in Central European history. Central European history is understood to include all German-speaking countries as well as areas previously included within the Habsburg monarchy. This year the prize competition is open to books published in 1996 or 1997, in English, by permanent residents of North America. Letters of nomination for the prize may be submitted by authors, publishers, or others and should be addressed to the chair of the book prize committee, Professor Vernon Lidtke, Department of History, The Johns Hopkins University, 3400 N. Charles Street, Baltimore, MD 21218. Nomination deadline: May 15, 1998.

Three copies of each book nominated should be submitted: one to the committee chair, and one each to the other two members of the prize committee, Professor Celia Applegate, Department of History, University of Rochester, Rochester, NY 14627, and Professor Robert Moeller, Department of History, University of California, Irvine, CA 92717 . Books should be postmarked no later than May 15, 1998. 
Email addresses of the book prize committee members:

Lidtke:

Applegate:

Moeller: lidtke@jhu.edu

capg@dbl.cc.rochester.edu

rgmoeller@uci.edu or rmoeller@ben

franklin.hnet.uci.edu

For further information about the book prize, please contact the Conference Group's Executive Secretary.

\section{Conference Group for Central European History Miscellaneous Announcements}

1998 Executive Committee. The members of the Conference Group's 1998 executive board are:

President:

Vice-President:

Vice-President Elect:

Immediate Past

President:

At-Large Member

(exp. January 1999):

At-Large Member

(exp. January 2000):

At-Large Member

(exp. January 2001):

Editor of Central

European History,

Executive Secretary

and Treasurer,
Gerald Soliday,

Ronnie Po-Chia Hsia,

Mary Jo Maynes,

Sybil Milton,

Evan Bukey,

Anson Rabinbach,

Mary Lindemann,

Kenneth Barkin,

Kees Gispen,
University of Texas, Dallas

New York University

University of Minnesota

Independent Scholar

University of Arkansas

Princeton University

Carnegie-Mellon University

University of California, Riverside

University of

Mississippi

1998 Nominations Committee. The members of the Conference Group's 1998 nominating committee are:
Charles Ingrao
Irmgard Steinisch
Jonathan Petropoulos
Department of History
Department of History
Department of History
Purdue University
York University
Loyola College 
West Lafayette

Indiana 47907

cingrao@purdue.edu
4700 Keele Street

North York

Ontario, Canada M3J I P3

irmgards@yorku.ca
4501 North Charles

Street

Baltimore, MD 21210

petropoulos@loyola.edu

Account balance of Prize Fund at the American Historical Association. The Conference Group maintains an interest-bearing endowment account with the American Historical Association. The first priority among the purposes of this account is to fund the annual article and book prizes. The fund's balance as of June 30,1997 was $\$ 14,847$.

\section{University of Toronto and German Historical Institute Conference Announcement Memory, Democracy, and the Mediated Nation Political Cultures and Regional Identities in Germany, 1848-1998 \\ An International, Interdisciplinary Conference Toronto, September 18-20, 1998}

The University of Toronto, in collaboration with the German Historical Institute (Washington D.C.), will host this interdisciplinary conference devoted to the themes of remembrance, liberty, local identity, and national solidarity. Bringing together about 45 invited scholars from Germany, Great Britain, the United States, and Canada, the discussions will focus on social and economic modernization in Germany since the mid-nineteenth century, the struggles of emancipatory movements, and the cultural codes that determine the prospects for national integration.

Participants have been asked to consider these themes from regional, national, and international perspectives. Many discussants will draw comparisons outward from one pioneering region of Central Europe: the Kingdom (later Free State) of Saxony. Others will consider how localism and regionalism present methodological challenges to scholars undertaking research across disciplinary boundaries.

Linked events are planned to take place on Friday, September 18, at the Canadian Centre for German and European Studies, York University, and the Goethe Institute, Toronto.

Coconveners for this event are James Retallack (Toronto) and Thomas Goebel (GermanHistorical Institute, Washington D.C.). 
For further information, including the tentative program, please consult the conference web site: www.chass.utoronto.ca/history/Memory

Readers who are not members and would like to join the Conference Group for Central European History may do so by subscribing to Central European History. Please contact the publisher, Humanities Press International, 165 First Avenue, Atlantic Highlands, NJ 07716-1289. Telephone: 732-872-1441. Fax: 732-872-0717.

Email:hpmarketing@humanitiespress.com. URL: http://www.humanitiespress.com/

Readers or members who would like to post information of interest to the profession or to other members of the Conference Group, should contact the executive secretary, Kees Gispen, at the following address:

Department of History

University of Mississippi

University, MS 38677

Telephone:601-232-7148

FAX:601-232-7033

Email: hsgispen@olemiss.edu 